UDC 635.21

HAC Code 06.01 .01

\title{
Development of variety technologies for cultivation of potato in the Middle Urals
}

\author{
F. Keita ${ }^{1}$, M. Yu. Karpukhin ${ }^{2 \bowtie}$ \\ ${ }^{1}$ Rural Polytechnic Institute for Education and Applied Research of Katibougou, Katibougou city, \\ Mali Republic \\ ${ }^{2}$ Ural State Agrarian University, Ekaterinburg, Russia \\ ${ }^{\bowtie}$ E-mail: mkarpukhin@yandex.ru
}

\begin{abstract}
Potato is one of the most important human foods. It possesses high taste and nutritional properties. The optimal ratio in potato tubers of organic and mineral substances necessary for a person determines its value as a food product. The tubers contain on average $76-78 \%$ of water and 13 to $36 \%$ of dry matter, of which $12-15 \%$ are starch, $1-3 \%$ protein and about $1 \%$ - mineral compounds. Potato proteins have a very high biological value, since they contain a complex of essential amino acids that are not synthesized in the human body and must be obtained from food. Potatoes are an essential source of vitamin C. The studies were carried out on the experimental field of the educational and experimental farm "Uralets" of the Ural State Agrarian University (USAU), the village of "Studencheskiy", for three years (2016-2018) in the climatic zone of the Middle Urals. Purpose of research. The objective of this study was to study the influence of the feeding area of Gala potato, the use of fungicides on the yield and quality of tubers in the conditions of the Middle Urals. Results. The results analysis on the mineral and biochemical composition of tubers showed that the total nitrogen content changed from 0.25 to $0.37 \%$ and did not depend on the feeding area. The phosphorus content varied from 0.034 to $0.063 \%$ and depended on the feeding area, i. e. the less often the plantings were, the more phosphorus was contained. Potassium content fluctuated over the years. The starch content was stable and did not depend on weather conditions and feeding area and ranged from 11.3 to $15.4 \%$. The tasting result showed that the studied potato variety Gala has high taste. According to the taste assessment, the Gala variety was rated 5 points in the control variant. The variant with the use of the fungicide "Shirlan" yielded to it by 0.5 points. Scientific novelty. The scientific novelty lies in the fact that for the first time in the conditions of the Middle Urals, the influence of the feeding area on the mineral and biochemical composition of potato tubers (nitrogen, phosphorus, potassium, dry substances, vitamin C and others). Keywords: potato, tuber quality, mineral composition, biochemical composition, nutritional area, fungicide, tasting, taste assessment.
\end{abstract}

For citation: Keita F., Karpukhin M. Yu. Development of variety technologies for cultivation of potato in the Middle Urals // Agrarian Bulletin of the Urals. 2020. Special issue "Biology and biotechnologies". Pp. 35-39. DOI: ...

Paper submitted: 11.11.2020.

\section{Introduction}

Potato is one of the most important crops and is rightly called the second bread. In the world production of crop products, it occupies one of the first places along with rice, wheat and corn. Potato contains almost all the essential enzymes and vitamins necessary for humans and animals, the most important of which is vitamin C. Its tubers contain up to $25 \%$ of dry matter and vital mineral salts, as well as trace elements. The main minerals and proteins in the tubers are unevenly located, concentrated under the skin or in the immediate vicinity of the surface, so tubers with an intact skin retain all nutritional benefits during storage and, as a rule, are not damaged by diseases. Red, yellow, white and brown tubers provide the human body with a significant amount of vitamins and minerals. For example, one medium potato contains about $620 \mathrm{mg}$ of potassium, which is more than bananas. Potassium is of great importance for humans, since it is involved in the regulation of muscle activity and affects the resistance of nerve cells to stress. Iron, which is found in potato, is involved in the conversion of food into energy, and is also important in the body's resistance to infections [15].
Potato is the fourth food crop in the world with a production of 377 million tonnes in 2016 after maize, rice, and wheat. China is the biggest producer of potato with an annual production of 99.13 million tonnes. Potato is commonly considered as a starch source due to the high starch content (65.90 to $74.08 \mathrm{~g}$ $100 \mathrm{~g}^{-1}$ dry weight, which is higher than that of the most used starch source - wheat (65.18 g $100 \mathrm{~g}^{-1}$ dry weight) [14].

Potato tubers contain about $25 \%$ dry matter, including $14 \ldots 22 \%$ starch, $1.4 \ldots 3.0 \%$ protein, about $1 \%$ fiber, $0.2 \ldots$ $0.3 \%$ fat and $0.8 \ldots 1.0 \%$ ash substances, organic acids $0.6 \%$, sugars $-1 \%$, water $-75 \%$. Potatoes are rich in vitamins $\mathrm{C}, \mathrm{B}_{1}, \mathrm{~B}_{2}, \mathrm{~B}_{6}, \mathrm{PP}$ and minerals. Young tubers are especially rich in vitamins [3], [7], [8], [12].

The raw potato is an important source of antioxidants, dietary material, $325 \mathrm{kcal}$ food energy, $7.6 \mathrm{~g}$ protein, $0.04 \mathrm{~g}$ fat, 72.8 g carbohydrates, $42 \mathrm{mg} \mathrm{Ca}, 231 \mathrm{mg} \mathrm{P}, 2.7 \mathrm{mg}$ Fe, $70 \mathrm{IU}$ vitamin A, $0.15 \mathrm{mg}$ riboflavin, $4.4 \mathrm{mg}$ niacin, and $64 \mathrm{mg}$ ascorbic acid. Furthermore, the potato is one of the most important food crops [9]. 
Moreover, the resistant starch $(22.50 \%)$ that promoted the digestion and regular movement of large intestine in the potato starch was higher than that of maize starch $(1.30 \%)$, wheat $\operatorname{starch}(1.00 \%)$, and rice starch $(6.50 \%)$ [6], [17].

In terms of nutrition, potato is a complex source of nutrients (vitamins, carotenoids, anti-oxidant phenolics, proteins, magnesium etc.), and some anti-nutrients (primarily glycoalkaloids). On average, potato tubers contain $77 \%$ water, $20 \%$ carbohydrates, and less than $3 \%$ of proteins, dietary fiber, minerals, vitamins and other compounds [16].

A hectare of potatoes provides up to four times the calories of a grain crop and up to $85 \%$ of the plant is edible human food, compared to around $50 \%$ in cereals. Potato produces more food per liter of freshwater used through irrigation than cereals and thus is more sustainable to mitigate the effects of climate change [1].

According to Hengsdijk H. W., De Boer J. [5], the causal factors enhance post-harvest losses through changes in the chemical composition and physical properties of the tuber in the process of respiration, loss of moisture from the tuber, sprouting, and spread of diseases.

Nitrogen is important in fuelling the growth by ensuring optimal photosynthetic production in leaves. Phosphate, particularly foliar phosphate is applied during inhabitation to increase the tuber and tuber size, thereby increasing the tuber yield. Potassium is absorbed in larger quantities throughout the growing seasons; it is required for high yields, it also influences the number of tubers. Calcium and Magnesium are applied during the bulking process to increase the size of the tuber. Micronutrients such as boron, copper, iron, sodium and zinc present in potato are essential for plant growth. So the deficiency of anyone may affect their growth. Boron is important for growth of plants in the structural and functional virtue of the plant cell. Copper aids in protein synthesis. Iron and zinc are essentially useful for crop growth and high yielding of plants [11].

Modern ideas about the consumer qualities of table potato varieties are associated with the shape and size of tubers, the depth of the eyes, the color of the peel and pulp, as well as the absence of external and internal defects due to the tendency of certain varieties to overgrowth, the formation of growth cracks, dullness, and a change in the color of the pulp (discoloration ) and other internal defects that may arise in tubers due to mechanical influences, especially during harvesting, transportation, sorting. In recent years, ideas about the nutritional value of potatoes as the most important product in human dietary nutrition have changed, due to the intensive development of selection in the direction of increasing the nutritional value of potato, as well as conducting in-depth studies in the field of its biochemistry. The biochemical composition depends on many factors: variety, soil and weather conditions, fertilizers, growing technology, degree of ripening, storage, etc. [13]

Several breeding and molecular approaches have been employed for trait improvement in potato. Conventional breeding techniques for potato improvement are directed to increase yield, processing, and storage-quality [4].

Although conventional breeding has been successfully employed for targeted trait improvement with less intraspecific variability, the progress is relatively slow and limited due to the phenotypic characterization of leading individuals in successive generations [2].

Many former studies have determined the nutritional qualities of potato cultivars which were planted in different areas, and indicated significantly different nutrients among different potato cultivars, which might be related to soil, climate, cultivation technologies, etc. [10] Some studies on potato cultivars were mainly concentrated on cultivating varieties of high yield and disease resistance, the information about nutritional and functional properties of different cultivars are scarce. Therefore, it is necessary to determine the nutrition compounds and evaluate the comprehensive value of different potato cultivars in order to increase the varieties which are adapted to the potato staple food [17].

In the Middle Urals, a new high-yielding, medium-early variety Gala has recently been spreading, characterized by relative resistance to diseases and good tuber preservation in winter. The cultivation technology of the variety under these conditions has not been studied; therefore, the study of the methods of cultivation of this variety is justified and relevant. The variety is included in the State Register of Breeding Achievements in 2008, and is approved for cultivation in the $2^{\text {nd }}, 3^{\text {rd }}$ and $4^{\text {th }}$ regions of the Russian Federation. The variety was used in this experiment by order of the Belorechensk farm of the Beloyarsk district of the Sverdlovsk region, where it is annually cultivated on large areas.

Purpose of the research: to study the effect of the food area of potato variety Gala, the use of fungicides on the yield and quality of tubers in the conditions of the Middle Urals.

Objectives: determine biochemical parameters and tasting assessment of potato tubers.

\section{Methods}

The object for the study was a variety of table potato, medium-early high-yielding Gala, bred by German breeders.

The research was carried out on the experimental field of the educational and experimental farm "Uralets" of the Ural State Agrarian University (USAU), the village "Studencheskiy", for three years (2016-2018) in the climatic zone of the Middle Urals. For the object of research in the experiment, we took a potato variety for table purpose, medium early, highyielding Gala, bred by German breeders, originator Norika (Germany). In the experiment, two fungicides were studied: "Shirlan" and "Infinito".

The soil of the experimental site is podzolized chernozem, according to its granulometric composition, it is heavy loamy with a humus content of $4.5 \%$, the reaction of the soil is weakly acidic, the availability of mobile phosphorus is low, exchangeable potassium is average. The depth of the arable layer is $25 \mathrm{~cm}$, the availability of the available forms $\mathrm{N}, \mathrm{P}$ and $\mathrm{K}$ is very low. Agrochemical parameters of soil: $\mathrm{pH}$, saline $=5.4 ; \mathrm{N}=185.9 \mathrm{mg} / \mathrm{kg}$ of soil $\mathrm{P}_{2} \mathrm{O}_{5}=238.9 \mathrm{mg} / \mathrm{kg} ; \mathrm{K}_{2} \mathrm{O}=$ $268.5 \mathrm{mg} / \mathrm{kg}$.

The experiment (two-factor) consists of 15 variants and 4 replications. The area of one plot is $20 \mathrm{~m}^{2}$ (width $=2.5 \mathrm{~m}$ and length $=8 \mathrm{~m}$ ), a total of 60 test plots, the total area of the experiment is $1200 \mathrm{~m}^{2}$. The placement of plots in the experiment is systematic. The row spacing is $70 \mathrm{~cm}$, and the distance between plants in a row is from 20 to $40 \mathrm{~cm}$. Influence of the feeding area (factor A) and the use of fungicides (factor B) on the yield and economic efficiency of potato cultivation in the Middle Urals. 
Biochemical analyzes of potato tubers were carried out in the analytical laboratory of the Ural Scientific Research Institute of Agriculture, a branch of the Ural Scientific Research Center of the Russian Academy of Sciences with the following methods: moisture (gravimetric method); mass fraction of nitrogen (crude protein) (Kjldahl method); fat (extraction method); raw ash (gravimetric); carotene (extraction); acidity, vitamin C (titrimetric method); sugar (ebuliostatic method); nitrates (ionometric); phosphorus (photometric method); potassium (flame photometric method) and fiber (method of removing acid-alkali-soluble substances from the product). For biochemical analyzes in each variant, $1 \mathrm{~kg}$ of potato tubers were taken during harvesting. The Agrotechnology of potato cultivation in the experiment was generally accepted for the Middle Urals.

\section{Results}

The results of the 2016-2018 studies have shown that the food area influenced the biochemical parameters of potato tubers of the Gala variety.

Indicators of mineral elements in potato tubers grown at different food areas are presented in table 1.

From the analysis of the data in table 1, it can be seen that the total nitrogen content changed from 0.25 to $0.37 \%$ and did not depend on the feeding area. The phosphorus content varied from 0.034 to $0.063 \%$ and depended on the feeding area, i. e. the less often the plantings were, the more phosphorus was contained. Potassium content fluctuated over the years. In 2017 (wet and cool) potassium was higher in tubers with a smaller feeding area, and in 2018, which was characterized by drier and warmer weather, on the contrary, more potassium was contained in tubers when they were rarely planted.

The biochemical parameters of potato tubers were also studied in table 2.

The experimental data obtained by us on the quality of tubers showed that the dry matter content depended both on the weather conditions over the years and on the planting density. Moreover, the larger the area of plant nutrition, the higher the dry matter content. There was a tendency to an increase in sugar content depending on an increase in the feeding area.

The content of vitamin $\mathrm{C}$ in cool, humid weather decreased with an increase in the feeding area, and, on the contrary, increased in warm, humid weather.

A strong reaction to changes in weather conditions was identified by the content of nitrates. In 2018, in warm, humid weather, the tubers contained 3.16 times more nitrates than in 2017 (dry and cool) with small feeding areas, and with large feeding areas, the differences increased up to 5 times.

The starch content was stable and did not depend on weather conditions and feeding area and ranged from 11.3 to $15.4 \%$.

The biochemical and mineral composition of tubers during storage, depending on the feeding area and the use of fungicides, are presented in table 3.

Analysis of the data in table 3 makes it possible to judge that the dry matter content in the variant with the "Shirlan" treatment and the $70 \times 35 \mathrm{~cm}$ planting scheme was higher than in the control and amounted to $19.17 \%$. When calculated per hectare, the dry matter yield in the control was $4500 \mathrm{~kg}$, and with the use of "Shirlan" $=7016 \mathrm{~kg} / \mathrm{ha}$, or $55 \%$ more. Vita-

Mineral composition of potato tubers depending on feeding area, 2017-2018

\begin{tabular}{|c|c|c|c|c|c|c|c|}
\hline \multirow{2}{*}{$\begin{array}{c}\text { Landing } \\
\text { scheme, } \boldsymbol{c m}\end{array}$} & \multirow{2}{*}{$\begin{array}{c}\text { Feeding } \\
\text { area, } \text { cm }^{2}\end{array}$} & \multicolumn{2}{|c|}{ Nitrogen, \% } & \multicolumn{2}{c|}{ Phosphorus, \% } & \multicolumn{2}{c|}{ Potassium, \% } \\
\cline { 3 - 8 } & 2017 & 2018 & 2017 & 2018 & 2017 & 2018 \\
\hline $70 \times 20$ & 1400 & 0.35 & 0.26 & 0.053 & 0.034 & 0.640 & 0.98 \\
\hline $70 \times 25$ & 1750 & 0.33 & 0.31 & 0.060 & 0.045 & 0.662 & 1.23 \\
\hline $70 \times 30(c)$ & $2100(c)$ & 0.27 & 0.25 & 0.052 & 0.038 & 0.605 & 1.21 \\
\hline $70 \times 35$ & 2450 & 0.31 & 0.33 & 0.063 & 0.043 & 0.660 & 1.19 \\
\hline $70 \times 40$ & 2800 & 0.37 & 0.30 & 0.062 & 0.053 & 0.690 & 2.00 \\
\hline$r$ & - & 0.08 & 0.47 & 0.65 & 0.79 & 0.49 & 0.81 \\
\hline
\end{tabular}

Table 2

Biochemical parameters of potato tubers depending on feeding area, 2017-2018

\begin{tabular}{|c|c|c|c|c|c|c|c|c|c|c|c|}
\hline \multirow{2}{*}{$\begin{array}{c}\text { Landing } \\
\text { scheme, } \mathbf{c m}\end{array}$} & $\begin{array}{c}\text { Feeding } \\
\text { area, } \mathbf{c m}^{2}\end{array}$ & \multicolumn{2}{|c|}{ Dry matter, } & \multicolumn{2}{c|}{ Sugar, \% } & \multicolumn{2}{c|}{ Vitamin $\boldsymbol{\text { mg \% }}$} & \multicolumn{2}{c|}{ Nitrates, $\boldsymbol{m g} / \mathbf{k g}$} & \multicolumn{2}{c|}{ Starch, \% } \\
\hline $70 \times 20$ & 1400 & 19.9 & 17.80 & 1.70 & 0.16 & 24.2 & 33.4 & 67.0 & 131.0 & 14.3 & 14.3 \\
\hline $70 \times 25$ & 1750 & 20.8 & 17.20 & 2.00 & 0.19 & 25.5 & 29.9 & 20.4 & 146.0 & 12.3 & 12.3 \\
\hline $70 \times 30(c)$ & $2100(c)$ & 20.0 & 17.70 & 2.28 & 0.17 & 23.8 & 33.9 & 22.5 & 138.0 & 11.3 & 12.3 \\
\hline $70 \times 35$ & 2450 & 21.2 & 17.60 & 2.42 & 0.24 & 23.3 & 31.2 & 20.9 & 137.0 & 11.8 & 11.8 \\
\hline $70 \times 40$ & 2800 & 21.6 & 18.60 & 2.10 & 0.21 & 24.2 & 33.0 & 30.2 & 133.0 & 12.3 & 15.4 \\
\hline$r$ & & 0.81 & 0.62 & 0.70 & 0.74 & -0.43 & 0.05 & -0.58 & -0.14 & -0.62 & 0.17 \\
\hline
\end{tabular}

Table 3

Biochemical and mineral composition of potato tubers depending on the feeding area and the use of fungicides,

2016-2018

\begin{tabular}{|c|c|c|c|c|c|c|c|c|c|}
\hline Variation & $\begin{array}{c}\text { Dry } \\
\text { matter, \% }\end{array}$ & $\boldsymbol{N}_{\text {totap }}$ \% & Phosphorus, \% & Potassium, \% & $\begin{array}{c}\text { Cellulose, } \\
\text { \% }\end{array}$ & $\begin{array}{c}\text { Sugar, } \\
\text { \% }\end{array}$ & $\begin{array}{c}\text { Vitamin } \\
\boldsymbol{C}, \boldsymbol{m g} \%\end{array}$ & $\begin{array}{c}\text { Nitrates, } \\
\mathbf{m g} / \mathbf{k g}\end{array}$ & $\begin{array}{c}\text { Starch, } \\
\boldsymbol{\%}\end{array}$ \\
\hline Control & 16.13 & 0.31 & 0.055 & 0.430 & 0.295 & 1.94 & 25.5 & 45.4 & 8.70 \\
\hline "Shirlan" & 19.17 & 0.26 & 0.062 & 0.503 & 0.368 & 1.79 & 27.7 & 57.0 & 8.70 \\
\hline
\end{tabular}


Tasting assessment of potato varieties, 2016-2018

\begin{tabular}{|c|c|c|c|c|c|c|c|}
\hline $\begin{array}{c}\text { Name } \\
\text { of samples }\end{array}$ & $\begin{array}{c}\text { Appearance } \\
\text { (color, tuber } \\
\text { shape) }\end{array}$ & $\begin{array}{c}\text { Tuber boiling } \\
\text { time, in } \\
\text { minutes }\end{array}$ & Soft color & $\begin{array}{c}\text { Consistency } \\
\text { softness }\end{array}$ & Digestibility & $\begin{array}{c}\text { Taste, } \\
\text { score }\end{array}$ & $\begin{array}{c}\text { Total } \\
\text { assessment, } \\
\text { score }\end{array}$ \\
\hline Gala+ "Shirlan" & White, rounded & 25 & Yellow & Rough & Weak & 4.5 & 4.5 \\
\hline Gala (control) & White, rounded & 23 & Yellow & Rough & Weak & 5.0 & 5.0 \\
\hline Irbit & Brown, rounded & 25 & Dark & Tender & Medium & 3.8 & 3.8 \\
\hline Mayak & Pink, oval & 14 & White & Tender & Medium & 4.0 & 4.0 \\
\hline Zekura & Grey, rounded & 22 & Yellow & Rough & Indigestible & 4.0 & 4.0 \\
\hline Luks & Red, rounded & 30 & White & Tender & Medium & 4.5 & 4.5 \\
\hline
\end{tabular}

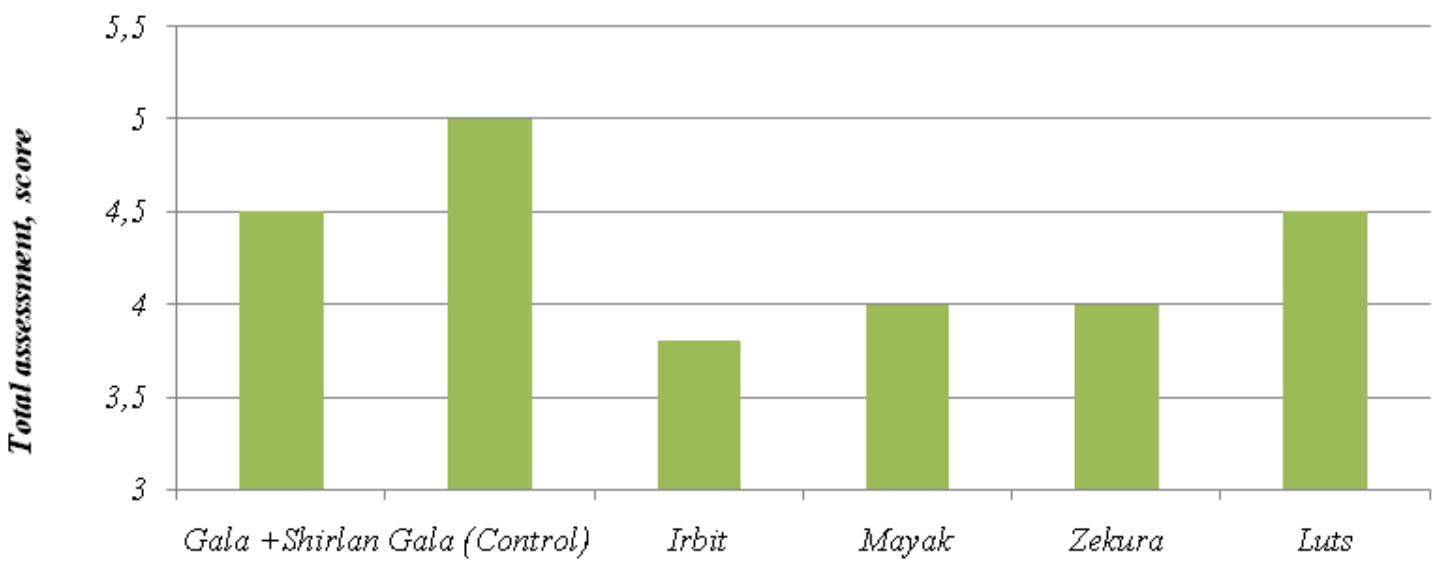

Name of sanqules

Fig. 1. Tasting assessment of potato varieties, 2016-2018

min $\mathrm{C}$ from 1 hectare in the control was $7114 \mathrm{~kg}$, and in the variant with the use of "Shirlan" - $10138 \mathrm{~kg}$ or $42 \%$ more. In the tubers of the control variant, the content of nitrates was $45.4 \mathrm{mg} / \mathrm{kg}$, and when using "Shirlan" $=57.0 \mathrm{mg} / \mathrm{kg}$. For other indicators, the differences were insignificant.

The quality of the products can also be judged by the results of the tasting, which showed that the studied potato variety Gala has high taste (table 4).

Of the five varieties, the most delicious variety was Gala in the control variant without fungicide treatment. It is interesting to note that the use of fungicides negatively affected the taste of the tuber. This happened, apparently, because the use of fungicides changed the concentration of cell sap, electrical conductivity, specific gravity of tuber, nitrate content and temperature of the tuber. Since the indicated indicators changed under the influence of the feeding area, then, apparently, the taste of potato tubers changed. The boiling time of tubers, depending on the variety, varied from 14 to 30 minutes.

Thus, from the studies carried out, it can be concluded that according to the taste assessment of Gala tubers, the control variant was the best variant; it was evaluated with 5 points. The variant with the use of the fungicide "Shirlan" was evaluated with 4.5 points, i. e. for 0.5 points less than control.

\section{Discussion and Conclusion}

Researches have shown that the food area influenced the quality of products, their mineral and biochemical composition, especially the content of nitrogen, phosphorus, potassium, dry matter, vitamin $\mathrm{C}$ and others.

The conducted studies allowed us to conclude that, according to the taste assessment of Gala tubers, the control option was the best, it was rated 5 points. The variant with the use of the fungicide "Shirlan" was evaluated with 4.5 points, i. e. for 0.5 points less than control.

With the use of the fungicide "Shirlan", the dry matter content was $7016 \mathrm{~kg} / \mathrm{ha}$, which is $55 \%$ more than the control. Vitamin C from 1 hectare in the control was $7114 \mathrm{~kg}$, and in the variant with the use of "Shirlan" $=10138 \mathrm{~kg}$ or $42 \%$ more. The nitrate content was $45.4 \mathrm{mg} / \mathrm{kg}$, and when "Shirlan" was used, it was $57.0 \mathrm{mg} / \mathrm{kg}$. For the rest of the indicators, the differences were insignificant.

\section{References}

1. Degebasa A. C. Prospects and Challenges of Postharvest Losses of Potato (Solanum Tuberosum L.) in Ethiopia // Global Journal of Nutrition \& Food Science. 2020. No. 2 (5). Pp. 1-10. DOI: 10.33552/GJNFS.2020.02.000550.

2. Hameed A., Zaidi S., Shakir S., Mansoor S. Applications of new breeding technologies for potato improvement // Reviez frontiers in Plant Science. 2018.Vol. 9. Pp. 1-15. DOI: 10.3389/fpls.2018.00925.

3. Devyatkina L. N., Sakov A. P., Ignatiev E. N., Polozova V. P. Scenarnoe prognozirovanie razvitiya kartofelevodstva s uchetom trebovaniy prodovol'stvennoy bezopasnosti regiona [Scenario prediction of the development of potato growing, taking into 
account the requirements of food security in the region] [e-resource] // Moscow Economic Journal. 2016. No. 3. Pp. $270-314$. URL: http://qje.su/ekonomika-apk/moskovskij-ekonomicheskij-zhurnal-3-2016-3/?print=print (appeal date: 07.10.2020). (In Russian.)

4. Halterman D., Guenthmer I., Collinge S., Butler N., Douches D. Biotech potatoes in the $21^{\text {st }}$ century: 20 years since the first biotech potato // American Journal of Potato Research. 2016. No. 93. Pp. 1-20. DOI: 10.1007/s12230-015-9485-1.

5. Hengsdijk H. W., De Boer J. Post-harvest management and postharvest losses of cereals in Ethiopia // Food security: the science, sociology and economics of food production and access to food. 2017. No. 9. Pp. 945-958.

6. Hung P. V., Vien N. L., Phi N. T. L. Resistant starch improvement of rice starches under a combination of acid and heatmoisture treatments // Food Chemistry. 2016. No. 191. Pp. 67-73.

7. Karpukhin M. Yu., Krupskiy I. N., Keita F. Tehnologiya vozdelyvaniya kartofelya na Srednem Urale [Potato cultivation technology in the Middle Urals: scientific and practical recommendations]. Ekaterinburg: Ural State Agrarian University, 2016. 15 p. (In Russian.)

8. Karpukhin M. Yu. Proektnyy keys: Razrabotka tehnologiy promyshlennogo vozdelyvaniya i semenovodstva kartofelya na osnove sovremennykh biotekhnologicheskikh metodov [Design case: development of technologies for industrial cultivation and seed production of potatoes based on modern biotechnological methods]. Ekaterinburg: Ural State Agrarian University, 2017. 21 p. (In Russian.)

9. Tunio M. H., Gao J., Shaikh S. A., Lakhiar I. A., Qureshi W. A., Solangi K. A., Chandio F. A. Potato production in aeroponics: An emerging food growing system in sustainable agriculture for food security // Chilean journal of agricultural research. 2020. No. 80 (1). Pp. 118-132. DOI: 10.4067/S0718-58392020000100118. URL: https://scielo.conicyt.cl/pdf/chiljar/ v80n1/0718-5839-chiljar-80-01-118.pdf (appeal date: 07.10.2020).

10. Ngobese N. Z., Workneh T. S., Alimi B. A., Tesfay S. Nutrient composition and starch characteristics of eight European potato cultivars cultivated in South Africa // Journal of food composition and Analysis. 2017. No. 55. Pp. 1-11.

11. Parameswaran R., Bhuvaneswar P. T. V. Detection of macro and micro nutrients in potatoes using elemental analysis techniques // International Journal of Recent Technology and Engineering (IJRTE). 2020. Vol. 8, Iss. 5. Pp. 1033-1040. DOI: 10.35940/ijrte.E6245.018520.

12. Sharipova D. S., Aitbayev T. E., Tazhibayev T. S., Nacheva E. K. The Impact of New and Improved Elements of Agricultural Technologies on Potato Productivity in the South-east of Kazakhstan // Biosciences Biotechnology Research Asia. 2016. Vol. 13 (2). Pp. 1031-1036. DOI: 10.13005/bbra/2129.

13. Simakov E. A., Anisimov B. V., Mityushkin A. V., Zhuravlev A. A., et al. Sorta kartofelya selektsionnogo centra VNIIKKH [Potato varieties of the breeding center of the All-Russian Research Institute of Potato Farming]. Consumer and dining quality, culinary type. Moscow, 2016. 38 p. (In Russian.)

14. Swieca M., Dziki D., Gawlik-Dziki U. Starch and protein analysis of wheat bread enriched with phenolics-rich sprouted wheat flour // Food Chemistry. 2017. No. 228. Pp. 643-648.

15. Tumanyan A. F., Tyutyuma N. V., Shcherbakova N. A. Biohimicheskiy sostav i kachestvo stolovykh sortov kartofelya, vyrashchivaemykh na svetlo-kashtanovykh pochvakh Astrahanskoy oblasti kapel'nym orosheniem [Biochemical composition and table quality of potato varieties grown in light chestnut soils of the Astrakhan region on drip irrigation] // Vestnik RUDN. Series: Agronomy and Livestock, 2016. No. 2. Pp. 1-8. (In Russian.)

16. Zaheer K., Akhtar M. H. Potato production, usage, and nutrition // Critical Reviews in Food Science and Nutrition. 2016. No. 56. Pp. 711-721. DOI: 10.1080/10408398.2012.724479.

17. Zhou L., Mu T., Ma M., Zhang R., Sun Q., Xu Y. Nutritional evaluation of different cultivars of potatoes (Solanum tuberosum L.) from China by grey relational analysis (GRA) and its application in potato steamed bread making // Science Direct, Journal of Integrative Agriculture. 2019. No. 18 (1). Pp. 231-245. DOI: 10.1016/S2095-3119(18)62137-9.

\section{Authors'information}

Fode Keita ${ }^{1}$, assistant in the department of plant protection, ORCID 0000-0001-7156-2623; +223 21 26-20-12, keitafode2016@gmail.com

Mikhail Yu. Karpukhin², candidate of agricultural sciences, associate professor, vice-rector for research and innovation, ORCID 0000-0002-8009-9121, AuthorID 339196; mkarpukhin@yandex.ru

${ }^{1}$ Rural Polytechnic Institute for Education and Applied Research of Katibougou, Katibougou city, Mali Republic

${ }^{2}$ Ural State Agrarian University, Ekaterinburg, Russia 